ECOLE is a Comenius 3 Network under the SOCRATES programme in the field of education running from 2002-2004. The main goal of Comenius Networks is to create links between projects carried out by school partnerships and those relating to the training of school education staff. This paper presents the outcome of the first year of the project with a special emphasis on the information and communication (ICT) infrastructure and the events. Project description covers an interactive website comprising information related to the activities of the network and an advisory reference point on running projects, database with projects, best practices, online teacher training, open working areas, project space, communication tools and so on.

The European Union has played an important role in supporting the use and development of ICT for pedagogical purposes in the schools of Europe, not only to the fifteen member states, but also to the EFTA/EEA countries (Iceland, Liechtenstein, Norway) and the associated countries from Central and Eastern Europe (Bulgaria, the Czech Republic, Estonia, Hungary, Latvia, Lithuania, Poland, Romania, Slovakia and Slovenia) and Cyprus, Malta and Turkey (European Union, 2003, http://europa.eu.int/)

There is also an EC/US cooperation programme comprising higher education and vocational education and training (http://europa.eu.int/comm/education/programmes/eu-usa/usa en.html), multinational partnerships for cooperation in higher education and training between EC and Canada (http://europa.eu.int/comm/education/canada/canada.html ) and pilot cooperation projects with Australia (http://europa.eu.int/comm/education/australia/australia.html) and Japan (http://europa.eu.int/comm/education/japan/japan.html).

SOCRATES is a community action programme in the field of education comprising eight separate actions:

- Comenius: school education

- Erasmus: higher education

- Grundtvig: adult education and other education pathways

- Lingua: learning European languages

- Minerva: information and communication technologies (ICT) in education

- Observation and innovation of education systems and policies

- Joint actions with other European programmes

- Supplementary measures (http://europa.eu.int/comm/education/socrates.html)

ECOLE is a Comenius 3 Network under the SOCRATES programme in the field of education running from 20022004. The main goal of Comenius Networks is to create links between projects carried out by school partnerships and those relating to the training of school educators. 


\section{The Consortium}

The network consortium consists of ten participating institutions from ten different countries representing a wide and complementary expertise and experience in the field of applied ICT-usage in compulsory education and in educational network organisations. The partnership includes universities, research institutes, pedagogical centres, local and national public authorities, and a large primary and secondary school. Countries involved are: the Netherlands, Italy, Slovenia, Portugal, Spain, the Czech Republic, Estonia, Denmark, Sweden and Norway.

1250 schools all over Europe are already in contact with ECOLE partners.

\section{Thematic Area}

The thematic area addressed by the ECOLE network is the educational use of ICT with the focus on how technology implementation can contribute to spreading the practice of Collaborative Learning at school.

The ECOLE Network is a networked and web-based organisation in which support for ICT-based collaborative learning projects and other innovative applications is offered. ECOLE aims at innovating didactic practice at school by using Information and Communication Technology (ICT) for Collaborative Learning projects.

\section{Overall Objective}

The overall objective of ECOLE is to make available content for collaborative learning projects, in combination with making available content for teacher education, and the creation of a learning community of teachers and pupils within compulsory education.

Teachers from primary and secondary education who are involved in COMENIUS projects compose the target group that will directly benefit from ECOLE activities. As most of the networked activity will point at offering online services, the activity of ECOLE network will also be helpful in spreading the best of COMENIUS culture in the schools that are still not directly participating in COMENIUS projects.

Students and pupils form a target group that will indirectly benefit from ECOLE activities, as they will be involved in the collaborative projects. Other educational institutions with interest in the area can benefit from the activities of the network: universities, public authorities as well as teacher training institutes.

\section{Main Activities}

ECOLE is a network of pedagogical institutions and schools offering teachers pedagogical advisory services, technological tools, resources to plan, run and evaluate collaborative projects according to their didactical needs. The main activities of ECOLE will include:

a) the establishment of the network itself;

b) the involvement of schools to be monitored;

c) the development of a website and web services;

d) the development of pedagogical materials;

e) an advisory service on ICT tools for education;

f) the implementation of virtual training activities.

The content of the ECOLE activity itself will be built in accordance with the best practices run under the COMENIUS umbrella. 


\section{Main Envisaged Outcomes}

Over the years the main envisaged outcomes of the network are:

a) a survey of COMENIUS best practice available on the web;

b) a platform for discussing projects and finding partners. Websites and a database of projects (in collaboration with European Schoolnet (http://www.eun.org), European Schools Project (http://www.esp.uva.nl/), and Socrates National agencies (http://europa.eu.int/comm/education/socrates/nat-est.html) will be linked to the central website;

c) educational materials derived from the projects;

d) a virtual advisory service about available Computer Supported Collaborative Learning tools;

e) information will be given to teachers on how to design and plan collaborative Comenius1 projects;

f) a taxonomy of ICT-based collaborative learning projects, to be reflected in web-based resources;

g) e-learning courses: teacher training materials and e-learning courses (for teachers and teacher trainers) are created on the basis of building blocks and conditions for successful European Collaborative Learning projects.

\section{Conferences}

Annual conferences are organized for teachers, other educational actors, national agencies, and policy makers. These conferences provide ample opportunity to explore ICT-tools for e-learning, and to design, plan and evaluate both content materials and computer-supported collaborative projects. In addition specific teacher training workshops are offered. Starting in the second year of activity ECOLE will also offer e-learning courses: teacher training materials and elearning courses (for teachers and teacher trainers) are created on the basis of building blocks and conditions for successful European Collaborative Learning projects.

\section{Impact}

The activity of ECOLE will have an impact on teachers target groups in several layers:

a) Teachers participating in projects will benefit from the collection of Comenius best practices and this will improve their skills in planning, running and evaluating such projects;

b) Teachers will benefit from the proposal of tools for collaborative teaching and learning. They will also be able to analyse the relationship between tools and the specific didactic content in terms of learning effectiveness;

c) Teachers will benefit from participating in virtual sessions of teacher training by having the possibility of following more courses than they could do by participating in presence;

d) Teachers will have online resources available to be sustained for all the duration of planned projects;

e) Teachers will have the possibility to have direct contacts with colleagues and experts during the conferences taking advantages from a supervision of collaborative projects from their very beginning. ECOLE will also impact on students, as some tools will be available for them for direct collaboration.

This paper presents the outcome of the first year with a special emphasis on the ICT infrastructure and the events: An interactive website comprising information related to the activities of the network and an advisory reference point on running projects, database with projects, best practices, online teacher training, open working areas, project space, communication tools etc.

As ECOLE is meant to be an open network, all the materials and service offered will be available for all teachers and librarians within compulsory education and also for teachers within teacher academies and in-service teacher training institutes, policy makers, universities etc. 


\section{ECOLE Infrastructure and Tools}

\section{Establishment of the Network Itself}

The ECOLE partners are all experienced ICT users, so establishing a network for this group was easily done. Our intention was, however, to use the same tools and environments that we were going to offer participants. This meant an interactive website, a virtual environment with workspace for different purposes and tools for virtual training activities.

\section{Development of a website and web services}

The project language is English and consequently the main website is in English (http://www.ecolenet.nl/). English is not always the first foreign language, however, so to be able to spread information about the project to as many as possible, the website is also available in Czech, Danish, Italian, Norwegian, Portuguese, and Slovenian languages. There are also summaries in Czech, Danish, Dutch, Italian, Norwegian, Portuguese, Slovenian, and Swedish languages.

\section{Events}

The Events button leads to extensive information about our conferences so far in the project:

\section{Bridges for Learning}

International Conference on the Educational Use of ICT for Collaborative Learning and Teaching Charles University Prague, Czech Republic. 12-14 September 2002 (http://it.pedf.cuni.cz/ECOLE/conf01.htm)

"Bridges for Learning" was the first conference organized by the Comenius 3 European Collaborative Learning Network. The focus of the conference was on three clusters of subjects:

1. Design, planning and evaluation of computer supported collaborative learning projects;

2. Teachers' professional development in internationalization, project-based learning and teaching, and ICT-usage;

3. Exploration of electronic learning environments and advanced ICT-tools for collaborative learning and teaching.

The conference was meant for primary and secondary school teachers, teacher educators, policy makers, and researchers. The spirit of collaboration was fostered by interactive sessions and workshops in which learning from and with each other was central: we all could share our projects, thoughts and ideas, thus building the bridges for learning.

The conference was also an international contact seminar for Comenius 1 projects. Teachers involved in Comenius 1 projects could use part of their budget to visit the conference. The programme included lectures and presentations on:

- The European Collaborative Learning Network - What is it?

- Theory - What are the backgrounds of Collaborative Learning?

- Best Practice - What examples do we have of CSCL-projects?

- Tools - What is the extra value of Electronic Learning Environments?

- Design, planning \& evaluation of CSCL-projects

- Presentation of Comenius projects

- Professional development of teachers in European perspective

- Lessons from Comenius 2 projects

- Internationalization

- An overview of Electronic Learning Environments

And also workshops for

- primary school teachers

- secondary school teachers, language

- secondary school teachers, math \& science

- secondary school teachers, social sciences

All presentations and documents are available in The ECOLE FC environment. 


\section{Bridging Best Practices}

The international conference Bridging Best Practices was promoted by the ECOLE network in co-operation with the European Schools Project (ESP). All ECOLE partners but one are actually board members of the European Schools Project, since the idea of creating the ECOLE network was born within ESP. The conference aimed at connecting the best practices in Computer Supported Collaborative Learning. 6-9 March, 2003 in Rome, Italy.

(http://www.ecolenet.nl/2003/)

This second conference was attended by 150 participants from 17 countries.

\section{Lectures, presentations}

The programme offered lectures of general interest such as:

- Bridging Best Practices: A Joint Event

- An Early Literacy Telecommunication Exchange Pilot Project

- The Comenius Best ICT Practices

- How to Describe Innovation

- How to Organize Your Project Evaluation

as well as several different strands like

- Language Teaching

- Exact Science

- Social Science

- Tools for Learning

- Teacher Training Opportunities

- Bridges to Other Nets

and lots of project presentations

All presentations and documents are available on the conference website (http://www.ecolenet.nl/2003 Go to Contributions!

\section{Workshops}

Workshops constitute a very important part of the conference. This is where experiences are shared, where new project proposals are born and where partnership is established. There were parallel workshops for language teachers, social science teachers, exact science teachers and head teachers with the possibility to move around for cross-curricula projects or perhaps as a messenger for a colleague back home.

Electronic forms on the conference site give the opportunity to send a proposal or information about an agreed project directly to a database. This on-line facility is available to anyone interested, not only those attending the conference. The ECOLE conference was also a Comenius contact seminar and thematic conference. (http://www.ecolenet.nl/contactseminar.html)

\section{Projects}

The Projects area invites you to the ECOLE project house. If you peek through the windows, you can find different project-related objects like:

- Project Help, where you find information about implementing international projects in schools (Stampe Rasmussen, Lise http://www.ecolenet.nl/projects/internationalisation.html) but also guidelines for evaluating your European project (McLeod, Rosetta http://www.aberdeen-education.org.uk/european/resources/guidef.htm).

- Educational Projects, which leads to Taxonomy and Examples of Internet Projects by our Czech partner Bofiivoj

Brdiãka. (http://omicron.felk.cvut.cz/ bobr/role/projects/). It includes a detailed taxonomy of project types, where Bofiivoj Brdiãka describes different categories of projects and links to several examples within each category based on the activity structure classification by Judi Harris, University of Texas at Austin (http://www.citejournal.org/vol1/iss3/seminal/article1.htm). 
- Project Presentations are intended as inspiration and help for teachers who are about to start.

- Project Proposals invites anyone interested to join in and start collaborating.

- ECOLE Best Club. The projects house has not only windows, but also a door leading to ECOLE Best Club. The club activities aim at developing an interactive platform to collect best practices, disseminate information and develop interactive resources to teachers involved in Computer Supported Collaborative Learning. The club offers links to projects, useful tools, on-line articles, distance training etc.

\section{A virtual environment}

Websites, mailing-lists and e-mail are all good tools for collaborative learning, but you also need a place to meet where you can communicate, where you can store your common documents etc. You need a community. There are lots of communities to choose among. Some cost money, some are free, at least at the start. We have chosen the First Class environment and made a deal with Centrinity AB, Sweden (Now OpenText) to use it for free for this project.

\section{Account}

By registering your interest on the ECOLE website, you get an account by e-mail and you are ready to join the community for free. You can use a web browser or a client, which is recommended especially for slow Internet connections.

\section{Personal Desktop}

The desktop you get, when you log in, looks different depending on who you are. The partners for instance have areas and conferences that are not visible to others. If a project group wants some private space for their project to save material and discuss things, while they are working, this area is also visible only to them. When you feel ready to share with the others in the community, we make it visible. Anyone involved in a collaborative learning project can get this for free.

\section{Mailbox}

When you send and receive internal mail (to and from others in the community), you use your real name (e.g. Ulf Akerberg), but you can also receive and send ordinary, external e-mail. When you send e-mail to someone outside the community, your e-mail address will be firstname.lastname@ecole.pedc.se and if someone outside the community wants to send you an e-mail, they use this same address (e.g. ulf.akerberg@ecole.pedc.se). An interesting feature in this environment is that you can see when/if people have read your message and downloaded attached files.

\section{Conferences}

There are general conferences for different purposes, folders with documents of various kinds: papers, presentations, forms, tips and good ideas etc.

\section{Calendar}

You have a personal calendar, but you can also get a group calendar for a project to share with your partners.

\section{Discussions}

You can get all sorts of discussion fora, for everyone or for a group.

\section{Chats}

There are different kinds of chat fora. There is a public chat that every community member can take part in, but you can also obtain a project chat forum or have private chats. 


\section{Tools for virtual training activities}

Many schools and institutions use the First Class environment for e-learning, but we wanted to offer some more functionality and made a company called Sigma Education co-operate on this with Centrinity (now OpenText). As a result of this the e-learning functionality of Sigma's product Colleen has been integrated into ECOLE First Class, which means that you reach both with a single login. To use Colleen you have to login to FC using a browser.

\section{What to do with Colleen}

Colleen is a tool to create and distribute course material. Every community member has the right to use this tool to inform, train or educate other members.

\section{Create a course}

You create a course by using the basic tools within Colleen. By choosing "Create document" you get a form to fill in Name of course item, Information about course item (e.g. questions or instructions) and Estimated study time, then click on Create and that is it.

A new toolbar is displayed with different tools to build the document:
Insert headline
Insert hyperlink
Insert text
Insert image/text
Insert text/image
Insert bullet list

Everything is done by filling in simple forms. After creating a course item you can edit it and make changes of course, but you can also re-use course items or give them to others to use.

You are not restricted to use the editing tools in Colleen. You can actually insert any kind of course item such as word-documents, pdf-documents, html-documents, flash-files etc. etc.

\section{Required Knowledge Test / Final Test}

When you have finished your course items, you can easily create a "Required knowledge test" and/or a "Final test" by linking questions to your course items in a form. To each question you have to enter "Answer alternatives". You also mark the appropriate "True" boxes to indicate which answer alternatives are correct. You can mark several answer alternatives as right, if you like.

The "Required knowledge test" tells the user what course items she/he should concentrate on, while the "Final test" hopefully indicates that the user has profited by the course.

When you have finished creating your course, with or without tests, you probably want to make it available. You do that easily by choosing "Add course to public courses". Then it is automatically available to all members of the community. Of course you can take it back and re-work it at any time.

\section{3-D ECOLE}

Students of all ages tend to be more particular about the user interface than many teachers. Probably because they are more used to virtual environments and are definitely more frequent users. One way to comply with the students' wishes is to explore new environments with perhaps more tempting features. One good example of this is Active Worlds Educational Universe, which is a 3-D platform, where you can create your own world adapted to your demands. (http://www.activeworlds.com/edu/awedu.asp) This will be offered later this year and will be announced on the ECOLE website. 


\section{Invitation to collaborate}

The project period ends in October 2004. Everyone interested in collaborative learning is invited to follow the further development of this project and also to take active part.

Next conference will take place in Prague in March 2004. Welcome!

\section{References}

Active Worlds Educational Universe. Retrieved May 26, 2003 from http://www.activeworlds.com/edu/awedu.asp

Brdiãka, Bofiivoj. Taxonomy and Examples of Internet Projects. Retrieved May 26,2003 from http://omicron.felk.cvut.cz/ bobr/role/projects/)

ECOLE Main Website. Retrieved May 26, 2003 from http://www.ecolenet.nl

ECOLE Conference Website 2002. Retrieved May 26, 2003 from http://it.pedf.cuni.cz/ECOLE/conf01.htm

ECOLE Conference Website 2003. Retrieved May 26, 2003 from http://www.ecolenet.nl/2003

ECOLE Contact Seminar. Retrieved May 26, 2003 from http://www.ecolenet.nl/contactseminar.html

ECOLE First Class. Retrieved May 26, 2003 from http://fc.ecole.pedc.se/

EC/US cooperation programme in higher education and vocational education and training. Retrieved May 26, 2003 from http://europa.eu.int/comm/education/programmes/eu-usa/usa en.html

European Schoolnet. Retrieved May 26, 2003 from http://www.eun.org

European Schools Project. Retrieved May 26, 2003 from http://www.esp.uva.nl/

European Union On-Line. Retrieved May 26, 2003 from http://europa.eu.int/

Harris, Judi. Teachers as telecollaborative project designers: A curriculum-based approach. Retrieved March 15, 2003 from http://www.citejournal.org/vol1/iss3/seminal/article1.htm

McLeod, Rosetta. Guidelines for Evaluating Your European Project. Retrieved March 15, 2003 from http://www.aberdeen-education.org.uk/european/resources/guidef.htm

Multinational Partnerships for Cooperation in Higher Education and Training between EC and Canada. Retrieved March 15, 2003, from http://europa.eu.int/comm/education/canada/canada.html

Pilot Cooperation Projects with Australia. Retrieved May 13, 2003 from http://europa.eu.int/comm/education/australia/australia.html

Pilot Cooperation Projects with Japan. Retrieved May 13, 2003 from http://europa.eu.int/comm/education/japan/japan.html

SOCRATES. Retrieved May 26, 2003 from http://europa.eu.int/comm/education/socrates.html

Socrates National Agencies. Retrieved May 26, 2003 from

http://europa.eu.int/comm/education/programmes/socrates/nat-est en.html

Stampe Rasmussen, Lise. Internationalization in Danish Schools. Retrieved March 15, 2003 from http://www.ecolenet.nl/projects/internationalisation.html 


\section{Biographical Note}

Ulf Akerberg (BA degree, Lund University) did some research on Swedish drama at Stockholm University in the early seventies. He worked as a teacher in upper secondary school until 1978. He was head teacher at Sodervarn College of Nursing from 1978-1994, where he developed educational software like Virtual Educational Hospital, Medical Mathematics, Medical Terminology and Medical English. Since 1991, he has been working with in-service teacher training and flexible learning in collaboration with Lund University and Malmo University. From 1994 he has been responsible for ICT development for pedagogical purposes and international projects at The Pedagogical Centre of Malmo. From 2002 he has been deputy director of this center. 